Vol. 10, N. 1, Year 2018

ISSN: 2037-0830 - DOI: 10.1515/rem-2018-0002

\title{
Evaluation Study of Early Formal Education Teacher Competence in Early Childhood Learning Dance at Kindergartens in Malang, Indonesia
}

\author{
Retno Tri Wulandari ${ }^{\text {a }}$, Usep Kustiawan ${ }^{\text {b }}$ \\ ${ }^{a}$ Malang State University, Malang, Indonesia.retno.tri.fip@um.ac.id \\ ${ }^{b}$ Malang State University, Malang, Indonesia.usepkustiawan@gmail.com. ORCID 0000-0001-9370-0505
}

\begin{abstract}
This study aims to define Early Formal Education teacher competence in the learning of dance art in kindergarten in Malang. This study uses a descriptive design with quantitative and qualitative approaches. The population is kindergarten teachers in Malang. The sample uses a proportional random sampling technique that amounted to 15 kindergarten teachers from five sub-districts in Malang, each sub-district represented three teachers from different kindergartens. The data collection technique used a questionnaire. The results show that the level of kindergarten teachers' understanding in Malang of the Early Formal Education teacher's competence required in the learning of dance art is in a good category; however, contrary to the reality in the field, the problem of early childhood dance learning lies in the lack of pedagogical competence, personality and teacher professionalism. Teaching requires intense and sustained training to improve dance learning competence. The conclusion is that the competence of Early Formal Education teachers in the learning of dance art in kindergarten in Malang is still lacking.
\end{abstract}

Keywords: Dance Learning; Early Childhood; Teacher Competence

\section{Introduction}

Teachers are one element of education implementers who play a role in producing qualified children and achieving optimal performance; therefore, teachers must have the competence to carry out their obligations and responsibilities with professionalism. In accordance with the Government Regulation of the Republic of Indonesia No 74 Year 2008 on Teachers, Article 3 paragraph 2, teacher competence includes pedagogical competence, personality competence, social competence and professional competence obtained through proficient education. These four competences have a great influence on learners and can change the attitudes, characters and thoughts of better learners. Competence according to Trianto (2011, p. 22) is understood as the ability, talent and skill possessed by someone who is responsible with the duty, position and profession. In addition, competence concerns the abilities and basic aspects of human beings, which are the cognitive domain (intelligence), affection (attitude), psychomotor (behaviour) and transcendental (moralreligious).

In the learning process, the main tasks of a teacher are teaching, educating and training students in achieving optimal cognitive, affective and psychomotor intelligence with competence. In order to carry out their duties properly, a teacher must have the skills and abilities in mastering the subject matter, delivering the lesson and evaluating it well. Teachers are a very dominant and important factor in general formal education because, for learners, teachers are often used as role models. Therefore, teachers should have adequate behaviours and competences to develop learners in their entirety. Teachers are required to master various things, especially personal, social and professional competence, to execute their duties well in accordance with the profession.

Teachers must master deep knowledge related to their respective fields of study, including other knowledge that correlates with the field of study. Therefore, their learning is not limited to the demands of the profession but also includes producing good and qualified students. Teacher competence is required to develop and demonstrate educational behaviour, in accordance with the Law of the Republic of Indonesia Number 14 Year 2005 on Teachers and 


\section{Evaluation Study of Early Formal Education Teacher Competence in Early Childhood Learning Dance at Kindergartens in Malang, Indonesia \\ Wulandari, Kustiawan}

Lecturers. That law provides that competence is a set of knowledge, skills and behaviours that must be possessed, lived and dominated by education and educational personnel in performing professional duties.

Increasing the potential and activity of early childhood in school is the teacher's responsibility. Therefore, teachers must have the skills and qualities to produce students who grow and develop in accordance with the appropriate stages. Moreover, it is known that children's development is diverse, both in terms of intelligence and other aspects of growth, because each child has unique characteristics, and sensitivity is very profound. Mastery of pedagogical and professional competence by Early Formal Education teachers greatly influence the implementation of learning dance in the field, appropriate or not with the concept of dance education in early childhood. Early Formal Education teachers should understand that learning dance in early childhood is more about art and education through art as a means of growing and developing individual learners in order to prepare for their future (Soeharjo, 2005, p. 3). It is not intended to be results oriented, with the goal of children becoming dance artists.

Four competencies (pedagogical competence, personal competence, professional competence and social competence) should be had by professional teachers in the field, because these competencies are linked directly to the achievement of teacher performance in the learning process. Performance of teachers on the tasks of planning, learning management and assessment of student learning outcomes. There must be commitment to the task of teaching a psychological bias in directing and guiding student learning activities so as to create effective learning indicators: concern for students' learning difficulties; participation in guiding student learning activities; creating a fun learning atmosphere; the presence of high willingness in teaching students and responsibility in the learning task (Hakim, 2015). The enabling of people to become autonomous, critical thinkers is included in the educational objective of Education for Sustainable Development as a central, general goal of education. Critical thinking should enable people to question their own lifestyle even with regard to the claim of sustainability, which implies that they need to be able (or, to be enabled) to understand and critically reflect the claim of sustainable development (Bertschy, 2013).

On the basis of the results of the preliminary study in Sukun and Kedungkandang sub-districts, which the researcher used in the dedication activity about the development of dance art learning in 2016, teachers have not met the standards as expected in legislation. The data from those sub-districts revealed many things. (1) Teachers do not have sufficient knowledge in terms of understanding the concept of dance learning, meaning that the art of dance is only used as a material for extracurricular activities or activities for the end of the year, focusing more on products or skills in dancing that require talent. The art of dance is not understood as a medium to achieve educational goals (education through art). (2) Teachers lack skills in managing the students in dance lessons. (3) Teachers' mastery on dance material is still lacking; there is incomprehension in the form or type of dance art that can be practiced by early childhood students, misconception between dance, motion and song and rhythmic gymnastics. All three are dance forms that can be practiced by children and have different characteristics. Frequently, in a contest event, teachers have the wrong concept in performing all three. (4) Teachers still have difficulty in applying dance art material and media selection that will be taught to learners because of the lack of knowledge of dance art; they still rely on material from the training held by education authorities. (5) There is a lack of self-improvement in training, workshops, conducting research or writing scientific papers, resulting in a lack of creativity in creating or developing their own materials and insufficiently addressing child-related issues of development art. On the basis of these data, the researchers have perceived that the competence of kindergarten teachers about dance lessons is not optimal, and this study will try to define Early Formal Education teachers' competences, especially in kindergarten in Malang in early childhood dance art learning.

According to Article 10 of the Teacher Law and Lecturer Jo, Article 28, Paragraph (3) PP No. 19 in 2005, an early childhood educator must have four educator competences, including pedagogical, personality, social and professional competence. On the basis of the problems that have been found in the field, the researchers did not examine all aspects of teacher competence in Article 3 PP No.74 Year 2008, but the researchers wanted to distinguish some of the teachers' competences related to problem-solving, described as follows: personality competence, related to the ability to master the development of early childhood dance and self-development in an independent and sustainable manner, and professional competence, related to teachers' abilities in mastering the concepts and methods of discipline relevant to scientific, technology or art and culture, which is conceptually covered or coherent with the educational unit programme that will be applied. On the basis of the description, the researchers chose the title of 'Study evaluation of early formal education teacher competence in early childhood learning dance at kindergartens in Malang, Indonesia'.

\section{Method}

This study used a descriptive research design with quantitative and qualitative approaches. This study attempts to define the evaluation of Early Formal Education teachers' competences in early childhood dance learning at 


\section{Evaluation Study of Early Formal Education Teacher Competence in Early Childhood Learning Dance at Kindergartens in Malang, Indonesia \\ Wulandari, Kustiawan}

kindergartens in Malang. The quantitative approach was used for data in the form of the percentage of teachers' competences in understanding that must be possessed in dance learning. The qualitative approach was used for data in the form of suggestions, definitions or input from research subjects about dance art learning problems and efforts to develop Early Formal Education teachers' competences in early childhood dance learning. The population was kindergarten teachers in Malang. The sample of the study used the proportional random sampling technique, which amounted to 15 Early Formal Education teachers, with each sub-district representing 3 teachers from different kindergartens. Five sub-districts were used as the samples: Blimbing, Klojen, Kedungkandang, Lowokwaru and Sukun.

Data collection techniques used questionnaires to obtain data on the Early Formal Education teachers' competences in dance arts learning. The questionnaire used a Likert-type scale to measure teachers' competences in Early Formal Education dance arts learning. The questionnaires used checklists and open fields. Closed questionnaires measured teachers' competences in the level of understanding that must be possessed in learning dance, and open questionnaires described learning dance issues and suggestions for the development of Early Formal Education teachers' competences in early childhood dance learning. The quantitative descriptive analysis technique was used to process data obtained through questionnaires in the form of descriptive percentages. Qualitative descriptive analysis techniques were used to process data in the form of advice or input from Early Formal Education teachers. The data were analysed using a descriptive statistical analysis with percentage calculations. A qualitative descriptive analysis was used to reveal information that was not revealed from a closed questionnaire.

\section{Results and discussion}

The results of the study on the evaluation of the Early Formal Education teachers' competences in early childhood dance lessons at kindergarten in Malang focus on the pedagogical competence, personality competence and Early Formal Education teachers' professional competences that are required in early childhood dance learning. The research data depict the teachers' competences that must be possessed in the learning of dance, the problems of learning dance and the development of Early Formal Education teachers' competences in early childhood dance learning. Data obtained based on questionnaires from respondents are described below.

\subsection{Early Formal Education teachers' competences in Learning Dance for early childhood at Kindergartens in Malang}

Teacher competence is the ability of teachers to carry out their duties and obligations in teaching, including at the level of early childhood education. This study examines the understanding of the competence of kindergarten teachers in Malang, focused on pedagogical, personality and professional competences, which are success factors in teaching dance art in early childhood. This is in accordance with Article 10 of the Law of Teachers and Lecturer Jo Article 28 Paragraph (3) of PP No. 19 of 2005, which determines the competence of educators as learning agents in elementary and secondary education and early formal education. This includes (a) pedagogical competence, (b) personality competence, (c) professional competence and (d) social competence.

On the basis of the results, teachers' understanding of the pedagogical competence that must be possessed by a teacher in teaching dance was $93 \%$ with an average score of 58 in either category; this demonstrates that Early Formal Education teachers in Malang understand the importance of pedagogical competence in dance learning. Therefore, the children's learning results can be achieved maximally. Such pedagogical competences include understanding the learners' characteristics in dance learning; the ability to design, implement and evaluate dance learning; and the utilisation of learning technology to support optimal learning results.

The pedagogical competence of kindergarten teachers in Malang in learning dance art must comply with Article 3 Government Regulation Number 74 Year 2008, which sets forth pedagogical competences that teachers must have. These include (1) students' understanding, (2) learning design, (3) implementation of learning that is educational and dialogical, (4) utilisation of learning technology and (5) evaluation of learning results (Trianto, 2010, p. 54).

In the ability of teachers to understand students in learning early childhood dance, the teacher is required to distinguish the character and the level of early childhood development and select dance movement materials in accordance with the children's movement abilities. Therefore, the materials conveyance or selected art learning method and teachers' materials mastery can be accepted by children in a more optimal and fun way. This is in accordance with the opinion that teachers' pedagogical competences should understand the most important things such as understanding the children's world, the characteristics of children and the process of children's education (Janawi, 2011, p. 68). 


\section{Evaluation Study of Early Formal Education Teacher Competence in Early Childhood Learning Dance at Kindergartens in Malang, Indonesia \\ Wulandari, Kustiawan}

Because teachers' ability is to understand the characteristics of learners related to the ability to organise children in dance learning. Early childhood has different characteristics, as seen from the aspects of motivation, interest and level of absorption and intelligence of children to dance. Moreover, the subject of arts development is often associated with children's talents and interests.

In relation to learning and evaluation design ability, kindergarten teachers in Malang also realise that teachers must have competence to design, implement and evaluate learning in accordance with the standard of curriculum content. This is in accordance with the opinion of Mahmud (2012, p. 70) Lesson plan, conducted by a teacher and a learner during the learning process, either for one meeting or several meetings.

The results of the study regarding teachers' personality competences in terms of the level of understanding that must be possessed by Early Formal Education teachers in art learning was $66 \%$, with an average grade of 49.3 in either category. The personality competences referred to in this study are focused on professional self-employed indicators by mastering the field of dance development and developing themselves independently and sustainably, in accordance with Article 3 of Government Regulation No. 74 of 2008 on personality competence that is self-developing independently and sustainably. In accordance with the Regulation of the Minister of National Education No. 16 of 2007 dated May 4, 2007, one of the personality competences of Early Formal Education teachers is working independently and professionally in relation to dance teaching; the indicator is that teachers are able to develop or educate professionally by mastering all aspects of early childhood development, including in the field of dance arts development and generating children's initiative to be creative in dance learning.

The understanding of kindergarten teachers in Malang about the personality competences that must be possessed by teachers in learning dance include the following indicators: (1) ability to develop or educate professionally by mastering the field of dance development and (2) attending a seminar, workshop, training and other self-development activities. This is in accordance with Satori's opinion $(2008$, p. 2.1) on the personality competences that must be possessed by teachers, one of which being that teachers are able to develop themselves in accordance with the renewal, both in their professional fields and their specialties. In relation to dance art learning, it means that Early Formal Education teachers are required to develop all aspects of early childhood development, and they are not limited to the field of dance. Therefore, teachers should be able to develop their knowledge and insight in understanding the concept and implementation of learning dance for children by joining a seminar, training or workshop on dance art for early childhood.

The results of the study on teachers' professional competences in understanding what must be possessed by Early Formal Education teachers in art learning were 67\%, with the average value of professional competence being 49.9 in the interval categorised as 'good'. It shows that kindergarten teachers in Malang certainly understand that professional demands must be possessed by teachers. In line with the opinion of Uno (2008) on teachers' professional competences, teachers should be able to master (1) scientific discipline as a source of instructional materials, (2) teaching materials taught, (3) knowledge of student characteristics, (4) knowledge and mastery methods and models of teaching, (5) mastery of the principles of learning technology and (6) knowledge of judgment and the ability to plan, lead and smooth the educational process.

Early childhood dance art learning teachers are required to have professional competence with the following indicators: having skills in teaching dance art for early childhood and the ability to develop art-based culture material for early childhood. In accordance with Article 3 of Government Regulation No. 74 of 2008 on teachers' professional competence, which is described as the ability of teachers in mastering the field of science, technology and/or art and culture. This covers the mastery of subject matter widely and deeply in accordance with the standard content of the programme unit education, subjects taught and the ability of teachers to master the concepts and methods of discipline science, technology or art and culture are relevant.

\subsection{Learning dance problems and efforts to develop the competence of Early Formal Education teachers in early childhood dance learning}

The results included qualitative data about real conditions in the field regarding the competences of kindergarten teachers in Malang in dance art learning. The results revealed that most teachers do not have sufficient pedagogical, personality and professional competences to teach early childhood dance art. Uncovered pedagogical competences include understanding of children's characteristics (physical, motor, emotional, social and cultural backgrounds) in following dance art; the characteristics of early childhood dance development; the lack of dance material planning tailored to the children's talents, interests and development; and lack of ability to motivate children to participate in 


\section{Evaluation Study of Early Formal Education Teacher Competence in Early Childhood Learning Dance at Kindergartens in Malang, Indonesia \\ Wulandari, Kustiawan}

moves in dance learning. Personality competence includes the lack of mastery in the field of early childhood dance development. The lack of sustainable self-development is demonstrated by the lack of frequent training or workshops on early childhood dance. According to data disclosed by respondents, in one year, there is not necessarily a training of competency enhancement organised by related educational institutions. Of the 15 teachers, 8 teachers have never attended dance training and 7 teachers rarely attend training, even less than one or two times a year. This is contrary to Article 3 of Government Regulation Number 74 Year 2008 regarding one of the demands of pedagogical competence that must be possessed by a teacher, which is independent and continuous self-development.

On the basis of the results in the field about dance teaching problems in kindergarten in Malang, the competence of teachers is much lower, especially the pedagogical, personality and professional competences that are not sufficient to teach early childhood dance art. Whilst theory and laws apply to all Early Formal Education, educators must have competence as a basic provision in designing, implementing and managing learning, in accordance with Masnipal's opinion (2013, p. 306) that Early Formal Education's teachers are required to have four competences: pedagogical, personality, social and professional competence. Pedagogical competences related to educational skills include the ability to plan, execute, process and evaluate. Personality competence is related to behaviour tailored to the characteristics of early childhood development, with an attitude of responsibility. Professional competence is related to the field mastery in handling early childhood.

Lack of pedagogical competence affects teachers' abilities in managing dance learning because of the lack of deepening the concept in dance art for early childhood. One example relates to the method of learning used by teachers who have experienced difficulties; therefore, they did not apply the variations of methods in dance learning. According to Mulyani's opinion (2016, pp. 114-122), alternative methods that can be used for learning dance in early childhood are (1) the storytelling method, which teachers should use before teaching dance and in which children are invited to talk about the dance theme to be used; (2) conversation, which can be used before and after the dance lesson; (3) the demonstration method, which can be used as a learning process of children's dance movement because it makes it easier when the teacher or children explain movements that have been done through demonstration, and the teacher can also improve children's understanding through sensitivity of sight and hearing; and (4) creative dance learning, which is the preferred aspect in helping children's abilities in the process or the way of thinking that produces something new or different. The emphasis is on the creativity of children in creating their own dance moves in accordance with what they think and feel. In the implementation of conventional dance, the children are only required to memorise the movement alone, but in creative dance, the goal is media development of children's creativity.

The data show the lack of teachers' professional competences in early childhood dance art learning, indicating that the teachers felt that they did not have enough background and knowledge about dance art and teachers did not deepen their knowledge on the concept and form of child dance art; the lack of ability and creativity in developing the material of motion and music of children and dance accompaniment; and lack of skills in delivering dance material for early childhood. Teachers feel that they do not have enough stock in the delivery of dance learning; therefore, the dance lesson is less suitable with the characteristics of early childhood, which is contrary to Setyawati's opinion (2012) that learning dance art during early childhood is categorised in play age groups around 4-6 years. At the age of playing, the ability of receiving dance material cannot be serious or solemn. Therefore, the terms of the dance material that can be used for early childhood are simple, practical and dynamic.

In practice, teachers who lack pedagogical competence and professional competence in early childhood dance lessons will not understand that the concept of art education for early childhood is not primarily product, but process, and art is used as a medium to achieve educational goals. This is not in accordance with John Dewey's opinion (in Dorn, 1994) that art is used to achieve educational goals, not for the sake of art itself. Art education plays a role in growing and developing appreciation of art, creativity, cognition, sensitivity, senses and emotions, as well as maintaining the mental balance of learners. Therefore, art education is suitable to be applied, because in its implementation, the process rather than the product is preferred. In other words, it can be concluded that learning the art of dance during early childhood should not only be seen from the ends, and the ability to perform dance moves from a technical aspect and aesthetics of the form of motion only. In accordance with Soeharjo's opinion (2005, p. 3) that art in Early Formal Education is more focused on art through functioning (education through art); that is, utilizing art as a means of growing and developing individual learners in order to prepare for the future.

The necessities delivered by Early Formal Education teachers in an effort to increase competence are numerous. They include (1) teachers training or workshops related to skills improvement, creativity, teacher skills to develop basic dance movements, learning how to explore children's artistic abilities, the development of art that also deals with the field of psychomotor skills in early childhood and the teachers' competences development in relation to dance learning; 


\section{Evaluation Study of Early Formal Education Teacher Competence in Early Childhood Learning Dance at Kindergartens in Malang, Indonesia \\ Wulandari, Kustiawan}

(2) more intense and continuous training by related educational institutions; (3) improving the ability of early childhood Learning Dance management, thereby maximising the results for early childhood from cognitive, affective or psychomotor aspects; (4) teacher needs on the availability of learning dance videos for early childhood teachers; (5) improvement of knowledge about various dance arts for children; (6) mastery of motion material characteristics appropriate with each child development stage; (7) improving the ability to comprehend the concept of dance and song form; (8) improving the skills of delivering dance materials, therefore, the children can easily understand and can follow the motion in accordance with the music's rhythm; (9) improvement in professional competence in the ability to comprehend the concept of traditional and modern dance; and (10) improvement of personality competence aspects of patience, skill and music.

\section{Conclusion and Suggestion}

\subsection{Conclusions}

The conclusions of this study are (1) kindergarten teachers' understanding in Malang Raya on the Early Formal Education teachers' competences that must be possessed in early childhood learning dance are focused on pedagogical competence, personality competence and professional competence. The level of teacher understanding is included in either category. (2) The problem of learning dance in the field is the unmet standard of kindergarten teachers' pedagogical, personality and professional competences in Malang City in dance teaching, whilst the effort that is conveyed by early childhood teachers to improve teachers' competence in learning dance is through increasing the knowledge and their skills in early childhood dance learning through the addition of training or workshop frequencies, and the need for learning dance videos for early childhood teaching.

\subsection{Suggestion}

This study suggests to improve the pedagogical, personality and professional competences of Early Formal Education teachers in Malang kindergarten in Learning Dance, which can be done with various efforts, such as through training, seminars, Teacher Working Groups, peer discussion, literature studies, further study and scientific writing. Various efforts can be applied to the development of pedagogical, personality and professional competences covering development to master learning materials and methods, as well as development to master the design, implementation and evaluation of dance learning, as well as professional development.

\section{References}

Adnan Hakim, (2015). Contribution of Competence Teacher (Pedagogical, Personality, Professional Competence and Social) On the Performance of Learning. IJES. Volume 4, Issue 2, PP.01-12.

Bertschy, Franziska, Christine Künzli, Meret Lehmann. (2013). Teachers' Competencies for the Implementation of Educational Offers in the Field of Education for Sustainable Development. Sustainability 2013, 5, 5067-5080; doi: $10.3390 /$ su5125067.

Government Regulation of the Republic of Indonesia No 74 of 2008, accessed on May 4, 2007

Law of the Republic of Indonesia Number 14 Year 2005 on Teachers and Lecturers, accessed on May 4, 2007

Law of the Republic of Indonesia Number 19 Year 2005 on Teachers and Lecturers, accessed on May 4, 2007

Masnipal (2013). SiapMenjadi Guru danPengelola PAUD Profesional. Jakarta: PTElex Media Komputindo.

Minister of National Education Regulation No. 16 of 2007, accessed on May 4, 2007

Mulyani, Novi (2016). PendidikanSeniTariAnakUsiaDini, Yogyakarta, Gava Media.

Satori, Djaman (2008). ProfesiKeguruan, Jakarta, Universitas Terbuka

Setyawati, Sri (2012). PendidikanSeniTaridanKoreografiuntukAnakUsiaDini (EdisiRevisi), Surabaya, Unesa University Press

Soeharjo (2005). PendidikanSenidarikonsepsampai program, Malang:BalaiKajianSenidanDesain FS

UniversitasNegeri Malang

Trianto (2011). PengantarPenelitianPendidikanbagiPengembanganProfesiPendidikandanTenagaKependidikan,

Jakarta, KencanaPrenada Media Group

Uno, Hamzah (2008). PerencanaanPembelajaran, Jakarta, BumiAksara. 